\title{
A COMPLETE FAMILY OF PERIODIG SOLUTIONS OF THE PLANAR THREE-BODY PROBLEM AND THEIR STABILITY*
}

\author{
M. HENON
}

Observatoire de Nice

\section{RESUMEN}

Se da una descripción completa de una familia de un parámetro, de órbitas periódicas en el problema plano de tres cuerpos con masas iguales. Esta familia comienza con una órbita rectilínea calculada por Schubart en 1956 y termina en revolución retrógrada, i.e., una jerarquía de dos binarias rotando en direcciones opuestas. Se calcula también la estabilidad de primer orden de las órbitas en el plano. Orbitas de revolución de tipo retrógrado son estables; más inesperado, órbitas del tipo "interplay", en el otro extremo de la familia son también estables. Esto indica la posible existencia de estrellas triples con movimiento enteramente diferente del arreglo usual jerúrquico.

\section{ABSTRACT}

We give a complete description of a one-parameter family of periodic orbits in the planar problem of three bodies with equal masses. This family begins with a rectilinear orbit, computed by Schubart in 1956. It ends in retrograde revolution, i.e., a hierarchy of two binaries rotating in opposite directions. The first-order stability of the orbits in the plane is also computed. Orbits of the retrograde revolution type are stable; more unexpectedly, orbits of the "interplay" type at the other end of the family are also stable. This indicates the possible existence of triple stars with a motion entirely different from the usual hierarchical arrangement.

\section{DISCUSSION}

King: When you say that an orbit is stable, does this include stability with respect to perturbations out of the plane?

Hénon: No. I have only computed the stability with respect to perturbation in the orbital plane. The stability with respect to perpendicular perturbation should certainly be also investigated, and this might eventually reduce the intervals of stability in the family.

In the particular case of Schubart's rectilinear orbit, however, stability in the plane automatically entails three-dimensional stability (because of the symmetry around the x-axis).

Abt: What fraction of the stable orbits would be confused with trapezium systems?

Hénon: In the stable orbits of the "interplay" type, the close approaches are of short duration. The resulting configurations could be classified as trapezium systems.

"Published: 1976 Celes. Mech., 13, 26. 